\title{
EXTERNAL AUDITORS' QUALITY, LEVERAGE, AND TAX AGGRESSIVENESS: EMPIRICAL EVIDENCE FROM THE INDONESIAN STOCK EXCHANGE
}

\author{
Eko Suyono \\ Faculty of Economics and Business Jenderal Soedirman University, Indonesia \\ Email:ekyo75@yahoo.com
}

Received: May 2018; Accepted: June 2018; Available online: July 2018

\begin{abstract}
This study aims to analyze whether external auditors' quality and leverage affect tax aggressiveness. Tax aggressiveness is one of the main issues with regard to tax compliance by corporations as taxpayers, particularly in developing counties such as Indonesia. Implementing purposive sampling approach, this study ended-up with 76 manufacturing companies listed on the Indonesian Stock Exchange for the 2012-2016 periods as a sample (i.e., 380 observations). By using OLS regression, the findings show that both external auditors' quality and leverage affect negatively on tax aggressiveness in-line with the theoretical concept and majority of previous studies. Therefore, this study contributes to the development of financial accounting and taxation research fields, particularly by providing empirical evidence from emerging market on the link between external auditors' quality, leverage, and tax aggressiveness.
\end{abstract}

Keywords: external auditors' quality, leverage, tax aggressiveness, tax compliance

\begin{abstract}
Abstrak
Penelitian ini bertujuan untuk menganalisis apakah kualitas auditor eksternal dan leverage berpengaruh terhadap agresivitas pajak. Agresivitas pajak merupakan salah isu utama yang berhubungan dengan ketaatan pajak perusahaan-perusahaan selaku wajib pajak badan, khususnya di negara-negara berkembang termasuk Indonesia. Dengan menggunakan pendekatan purposive sampling, penelitian ini berhasil mendapatkan 76 perusahaan manufaktur yang tercatat di Bursa Efek Indonesia untuk periode 2012-2016 sebagai sampel (380 observasi). Dengan menggunakan regresi OLS, hasilnya menunjukkan bahwa kualitas auditor eksternal dan leverage berpengaruh negative terhadap agresivitas pajak sesuai dengan beberapa teori yang mendasari penelitian ini dan mayoritas hasil-hasil penelitian terdahulu. Dengan demikian, penelitian ini berkontribusi terhadap pengembangan penelitian-penelitian di bidang akuntansi keuangan dan perpajakan, dengan memberikan bukti empiris dari negara berkembang mengenai hubungan antara kualitas auditor eksternal, leverage, dan agresivitas pajak.
\end{abstract}

Kata Kunci: kualitas auditor ekxternal, leverage, agresivitas pajak, ketaatan pajak

How to Cite: Suyono, E. (2018). External Auditors' Quality, Leverage, and Tax Aggressiveness: Empirical Evidence from The Indonesian Stock Exchange. Media Ekonomi dan Manajemen, 33(2), 99-112. 


\section{INTRODUCTION}

Tax is a mandatory duty binding on all citizens as well as corporations and must be paid to the state. On the other hand, tax is the main source of income for most countries including Indonesia, where for Indonesia in the past decade the percentage of taxes in the state budget has increased up to more than $60 \%$ of the source of state income (Annisa and Kurniasih, 2012; Astuti \& Aryani, 2016). Mansor and Gurama (2016) argued that taxes are generally the main source of income which is subsequently used to sustain development funding in most of the world, especially in developing countries including Indonesia.

The fundamental problem faced by most countries is the prevailing phenomenon in which the revenue from tax sources is still far from the potential that should be because there are efforts from the taxpayers to do the tax avoidance or evasion which are considered. Eschborn (2010) explained that tax evasion is an attempt against the laws and regulations that exist to not pay taxes. While tax avoidance is deliberate efforts to minimize the amount of taxes that should be paid by looking for legal loopholes so as to imply their actions do not violate laws and regulations in the related state (Simser, 2008; Armstrong et al., 2015).

In other words, tax collection is often not maximized because there are attempts by taxpayers to avoid paying taxes or minimizing tax payments in ways they deem legal. So tax avoidance/evasion is a very basic problem for most developing countries, including Indonesia because it causes tax revenue to be not optimal. Moreover, taxpayers who generally make efforts to avoid taxes are corporate taxpayers whose the tax amount they try to avoid is significant in reducing the total amount of taxes they should pay to the state. This condition is exacerbated by the large number of corporate taxpayers who consider that the tax is a burden for companies that can reduce net income so that most companies do not pay taxes voluntarily. Since there are still many companies' managers who think that taxes are a burden, many companies are trying to minimize the tax payment in a way that does not violate the law that so-called by tax avoidance (Kurniasih \& Sari, 2013).

One of the expectations by the Directorate General of Taxes in tax revenue is the manufacturing industries because this sector is the most dominant type of industry both in terms of the number of companies as well as the number of annual profits they generate so as to also contribute to the number of state revenue from taxes they pay. Moreover, the data show that the manufacturing industry in Indonesia experienced the greatest growth compared to other industry sectors by $4.12 \%$ in 2012 from $4.10 \%$ in 2011 (Astuti \& Aryani, 2016). Moreover, in 2010 , the contribution of value-added tax in the manufacturing sector increased to $46 \%$, then jumped $60.5 \%$ in 2011 and increased again to $74.2 \%$ in 2012, meanwhile, for income tax contribution increased to $34.7 \%$ in $2010,41.9 \%$ in 2011, and again increased by 55\% in 2012 (Astuti \& Aryani, 2016). Nevertheless, there remains a gap between acceptable revenue and actual tax revenues in the manufacturing sector either from income tax, value-added tax, and other taxes related to the manufacturing sector. The revenue gap is caused by the low compliance of tax deposits, the number of undocumented transactions (underground economy) and the tendency of tax avoidance (Astuti \& Aryani, 2016).

In the United States, at least onequarter of the company has tax avoidance by paying taxes less than $20 \%$ while the average tax paid by the company is close to $30 \%$ (Dyreng et al., 2008). Similarly in Indonesia, in 2005 there were 750 Foreign Investment Companies suspected of tax avoidance by reporting company losses for five consecutive years and not paying taxes to the state (Astuti \& Aryani, 2016). Furthermore, in 2012 there are 4000 PMA 
companies reporting zero taxes due to the loss for seven consecutive years, where generally the company is engaged in manufacturing and processing of raw materials (Astuti \& Aryani, 2016).

There are several factors influencing tax avoidance from previous studies, namely profitability, family ownership, independent board of director, audit committee, firm size, leverage, fiscal loss compensation, etc (Richardson \& Lanis, 2007; Dyreng et al. 2008). This study tries to be more specific to analyze two factors that are expected to contribute in tax avoidance practices that is auditor quality and company leverage by taking sample of the study from manufacturing companies listed in the Indonesian Stock Exchange because the manufacturing companies are the most dominant in the Indonesia Stock Exchange as has been explained in the above paragraph.

The external auditor from the public accounting firm is an independent party that is expected to be able to increase the value of financial statements for its stakeholders through the audit activities on the financial statements. The external auditor will assess the fairness of financial reporting along with all existing disclosures by comparing them with generally accepted accounting principles (GAAP). In doing the audit work, the auditor will also assess the reasonableness and validity of reporting items related to the company's profit which automatically also affects the amount of tax to be paid. Thus the existence of an external auditor will affect the aggressiveness of the company in making efforts of tax avoidance or tax evasion. Donohoe and Knechel (2014) argued that aggressive corporate tax planning efforts may increase the litigation risk for the auditor because it may be that shareholders will hold auditors accountable in case of a tax bill from the tax office due to a tax-deficit in one fiscal year. The tax office may prosecute the company as a result of the company's failure to comply with taxes in accordance with applicable law and regulations and this condition will have implications for the auditor's reputation because the auditor will be deemed to have failed to perform its duties to ensure adequate disclosure activities in the company's financial statements for not adequately disclosing the amount of taxes that should be paid to the state (Hennes et al., 2014; Kanagaretnam et al., 2016). Furthermore, Hanlon et al. (2012) argued that the existence of tax planning activities that are too aggressive by the company will raise public doubts about the quality of its auditors because the public will argue that the auditor does not perform the audit work strictly following the professional standards of public accountants and not strictly apply the principles of professional ethics so that although the financial statements have been audited by an independent external auditor, tax avoidance or tax evasion occurred through highly aggressive tax planning. In other words, a good auditor's reputation from large public accounting firms (i.e., Big 4) will be able to prevent overly aggressive tax planning practices that can be interpreted as a client's attempt to avoid tax payment.In addition to the quality of external auditors, this study predicts that firm leverage is also another factor that will affect the aggressiveness of companies in tax planning. This is because leverage represents the financing of an enterprise where debt reflects the higher value of the firm in which leverage is also an addition to the amount of debt that results in additional interest expense that can reduce the corporate income tax expense. Richardson and Lanis (2007) examined the effect of leverage and company size on tax avoidance and stated that the higher the leverage ratio the lower the effective tax rate (ETR) of the firm is due to the interest expense that reduces the tax expense. It means that leverage has a negative effect on tax avoidance. Richardson and Lanis (2007) said the bigger the company will be the lower ETR it has, this is because big 
companies are better able to use the resources it has to make a good tax planning. Some previous studies indicated that there is a deliberate attempt by the company to increase the amount of the debt so that the company are able to avoid the payment of taxes because with large debts resulting in the huge interest expense to be paid where the interest expense will reduce the company's profit that will also automatically reduce the corporate tax (Desai \& Dhamapala, 2006; Sartori, 2008). Lennox et al. (2013) argued that companies that do tax planning aggressively tend not to commit accounting fraud. Meanwhile, Gallemore et al. (2014) found no significant relationship between aggressive tax planning and auditor reputation.

Based on the above problems, the purpose of this study is to: (1) analyze the effect of the quality of external auditors on tax aggressiveness, and (2) to analyze the effect of leverage on tax aggressiveness.

\section{LITERATURE REVIEW AND HYPOTHESES DEVELOPMENT}

\section{Literature Review}

Relationships among variables in this study can be explained by positive accounting theory (Watts \& Zimmerman, 1986) and economic regulation theory (Hertog, 1999). From the perspective of positive accounting theory, the taxes that companies must pay to the state treasury can be viewed as part of the political costs whereby the bigger the company will pay the greater political costs. This will ultimately lead managers to look for ways to minimize the reported earnings in the financial statements so that they can pay taxes at a smaller amount, which is a tax avoidance measure by companies. Hence in the concept of a political cost hypothesis, larger companies automatically have more wealth so that they will become political victims by paying greater political costs, such as by paying a larger tax amount which is marked by the larger ratio of effective tax rate (ETR) (Watts and
Zimmerman, 1986). However, Siegfried (1972) has a different view in which he argued that the larger the company will have more resources that they can use to aggressively make a tax planning to optimize the tax savings so that the ETR will be even smaller. In other words, the smaller the ETR ratio indicates that the company has done a very aggressive tax planning that is often called by the tax avoidance. This means that a small ETR ratio indicates the amount of cash paid in the form of taxes to the state disproportionate to the amount of profit earned by the firm.

Meanwhile, from the perspective of economic regulation theory, Hertog (1999) argued that the economic problem is not merely a transaction of profit or loss or effectiveness and efficiency, but concerns the dimensions of justice, power-sharing arrangements, etc. The theory of economic regulation means that the economy must be built in a certain social relations context where the economy is not only about rational choice, maximization (Pareto optimum) principle, transaction cost, but also about deep-rooted habits community. With regard to the tax payments by taxpayers, the theory of normative economic regulation argues that government will expect all taxpayers to be obedient and have the awareness to pay taxes (Hertog, 2010). However, in reality, not all taxpayers have the awareness to pay their taxes, in general, they make aggressive tax planning efforts to make the tax savings optimally by trying to pay the smallest amount of tax, which in turn is known as positive economic regulation theory (Hertog, 2010).

\section{Hypotheses Development}

\section{External Auditors' Quality and Tax Aggressiveness}

The external auditor of the public accounting firm plays a role in assessing the fairness of the financial statements made by the company in all aspects, in 
terms of recognition, measurement, reporting, or disclosure. In carrying out its work the auditor will pay more attention to material transactions, including income tax expense which is generally of very material amount compared to net income before tax. Barrett (2004) argued that the auditor is obliged to scrutinize the amount of tax debt in the company's balance sheet and the tax expense contained in the income statement as well as the feasibility of disclosing the items relating to both accounts in the company's financial statements. Thus the auditor's professional duty is to examine whether there are unlawful tax-related transactions, which can minimize the company's efforts to conduct aggressive tax planning in the form of tax avoidance or even in tax evasion.

The auditor has the ability to control or suppress the client to reduce his/her aggressive tax behavior because aggressive tax behavior has the potential to increase the likelihood of the client performing material misstatements in the financial statements due to the use of multiple accounts such as allowances for assessments, tax contingency reserves, estimated accrued taxes, etc (Hanlon \& Heitzman, 2010; Gupta et al., 2016). In addition, aggressive tax behavior may also be detrimental to the auditor as it will increase the risk of litigation when the government discovers a violation committed by the client with regard to its tax obligations (Heninger, 2001; Palmrose \& Scholz, 2004). In addition, some previous studies have found that aggressive tax planning can also worsen the company's reputation that could ultimately lower the company's share price (Hanlon \& Slemrod, 2009; Kim et al., 2011). When It happens, it can certainly trigger lawsuits against auditors from shareholders who feel aggrieved as the auditor does not strictly control the manager to avoid aggressive tax planning (Francis et al., 1994).
This study argues that the larger the size of a public accounting firm will be more reputable. Following some previous studies, this study argues that auditors from the Big 4 public accounting firms are more reputable than auditors of the non-big four (Choi et al., 2008; Francis \& Wang, 2008; Kanagaretnam et al., 2010). Further Mansi et al. (2004) found empirical evidence that Big 4 public accounting firms were better able to guarantee the quality of their audits compared to smaller public accounting firms. So some previous studies documented that aggressive tax planning is more prevalent in firms audited by non-Big 4 public accounting firms than firms audited by Big 4 public accounting firms (Frank et al., 2009). Other studies have found several public accounting firms set higher audit fees when there are indications of aggressive tax planning by the clients as compensation for the litigation risks they may face if the government finds clients' mistakes with regard to its tax obligations (Donohoe \& Knechel, 2014; Klassen et al., 2016 ).

Furthermore, Lisowsky (2010) documented that the size of public accounting firm will be positively related to tax protection activities where in general the larger the public accounting firm will be increasingly reputable so that they will be obedient to the prevailing laws and regulations and often characterized as tax promoters. McGuire et al. (2012) found that public accounting firms providing audit services and tax consulting services simultaneously encourage increased aggressive tax behavior of the client.

Based on the various arguments above, the first hypothesis in this study formulated as follows:

$\mathrm{H}_{1}$ : External auditors' quality affects negatively on tax aggressiveness

\section{Leverage and Tax Aggressiveness}

The companies in the choice of their capital structure are enabled to use debt as an alternative source of external financing. One proxy of capital structure is leverage, 
which is a ratio that measures how far a company uses debt in financing. Leverage also describes the relationship between total assets with common stock or shows the use of debt to increase profit. However, the debt will create a fixed interest expense, where the greater the debt the greater the interest payable which implies the smaller net profit before tax reported in the financial statements. In other words, the greater the debt will further reduce the taxable income because of tax incentives on the greater of debt interest. This condition often influences the behavior of managers in preparing alternative capital structures where managers have the initiative to increase the company's debt as well as the source of funding to minimize the tax expense. This condition is in accordance with article 6 of Indonesian Law No. 36 of 2008 stating that interest on loans is one type of expense that can be deductible in tax calculation (deductible expense).

Ozkan (2001) provided evidence that firms with high tax liabilities will choose to make loans in order to get tax deductions, so this deliberate indebtedness falls under the category of aggressive action against taxes. Higher interest rates will affect the company's tax expense. The higher the company's debt ratio, the lower the company's CETR (Cash Effective Tax Rate) ratio (Richardson \& Lanis, 2007). This is in line with Swingly and Sukartha (2015) who found that the higher the leverage the lower the tax avoidance that companies do because of the interest expense. The results of Richardson and Lanis (2007) also stated that leverage has a negative effect on tax avoidance. Furthermore, Stickney and McGee (1982) and Gupta and Newberry (1997) also found a negative relationship between tax avoidance with ETR and leverage. As long as inventory intensity is a substitute for capital intensity, intensive inventory of firms must have a higher ETR (Zimmerman, 1983). Gupta and Newberry (1997) provided evidence that firms with larger proportions of fixed assets have lower ETR due to tax incentives, while firms with larger inventory proportions have a higher ETR.

Based on the various arguments and results of the previous studies above, the second hypothesis is formulated as follows:

$\mathrm{H}_{2}$ : Leverage affects negatively on tax aggressiveness.

\section{RESEARCH METHODOLOGY}

\section{The Sample of the Study}

The population of this study is all manufacturing companies listed on the Indonesia Stock Exchange for 2012-2016 periods, i.e., 148 companies. Then, this study empowers purposive method in sampling collection with criteria as follows:

\section{Variables Definition and Measurement}

\section{Dependent Variable}

As the dependent variable in this study is tax aggressiveness which is measured by using effective tax rate (ETR). It is calculated with the formula as income tax expense divided by book income (Richardson \& Lanis, 2007). The smaller ETR shows that the amount of tax expense paid is not proportional to the company's net income. This condition indicates that the company conducts aggressive tax planning in the form of tax avoidance.

\section{Independent Variables}

External Auditors' Quality

The quality of external auditors in this study is measured by using a dummy variable where the score 1 is given when the company is audited by the Big 4 public accounting firm, otherwise, the score 0 is given (Kanagaretnam et al., 2016; Langli \& Willekens, 2017).

\section{Leverage}

Leverage (LEV) in this study is measured by formula as follows 
(Richardson \& Lanis, 2007; Farooque et al., 2014):

$$
L E V=\frac{\text { Long-Term Debt }}{\text { Total Assets }}
$$

\section{Data Analysis}

Data analysis in this study includes descriptive statistic, classical assumption of multiple regression (i.e., normality, heteroscedasticity, autocorrelation, and multicollinearity). After all the classical assumptions are met, multiple regression tests are performed by using ordinary least square (OLS). Furthermore, the regression equation in this study is presented as follows:

$$
\mathrm{TAXAG}=\alpha-\beta_{1} \mathrm{AQ}-\beta_{2} \mathrm{LEV}+\varepsilon
$$

$$
\begin{array}{ll}
\text { Where: } & \\
\alpha & =\text { Constant } \\
\beta_{1}-\beta_{2} & =\text { Regression coefficient } \\
\text { TAXAG } & =\text { Tax Agresiveness } \\
\text { AQ } & =\text { External Auditors' Quality } \\
\text { LEV } & =\text { Leverage } \\
\varepsilon & =\text { error }
\end{array}
$$

\section{RESULTS AND DISCUSSION}

\section{The Descriptive Statistic}

The result of the descriptive statistic in this study is presented in Table 2. Table 2 presents the descriptive statistics of the variables in this study. The results show the relatively high average leverage of sample firms with an average of $54 \%$, meanwhile, the average of tax aggressiveness proxied by ETR is $21 \%$.

\section{Classical Assumptions of Regression}

The results of classical assumptions testing that include normality, heteroscedasticity, autocorrelation, and multicollinearity show that the model in this study meets all of these assumptions. This study uses One-Sample Kolmogorov-Smirnov for normality test as presented in Table 3.
Table 3 shows the value of Asymp. Sig is higher than $\alpha(0.05)$. It means that the data in this study is normally distributed.

Then, to test the heteroscedasticity, this study uses Park Gleyser test as presented in Table 4 . Table 4 presents that the significant values (Sig.) of the independents variables (i.e., AQ and LEV) on the absolute residual (ABRESID) are higher than $\alpha(0.05)$. It means that no heteroscedasticity problem in the model of this study.

Furthermore, this study uses DurbinWatson (DW) test to prove the autocorrelation problem. The output of DW test is presented in Table 5. The result of autocorrelation test in table 5 shows that the value of DW is 1.886 which is between the upper bound (du) and 4-du). From the Durbin-Watson table, the value of DU for two independent variables $(\mathrm{K})$ and 380 observations $(\mathrm{N})$ is 1.748 . It means that the value of DW test (1.886) is between $1.746(\mathrm{du})$ and 2.254 (4-du). Therefore, it could be concluded that the model on this study is free from the autocorrelation problem.

Lastly, to test the multicollinearity problem could be seen from the value of Variance Inflation Factor (VIF) as presented in Table 6 . Table 6 shows that the value of VIF for both independent variables is lower than 10 . It means that the model in this study is free from multicollinearity problem.

\section{Results}

The summary of regression analysis results in this study is presented in table 7 . Table 7 shows that both independent variables in this study, i.e., auditor quality and leverage influence negatively on tax aggressiveness with a significant value of 0.009 and 0.012 respectively which are lower than $\alpha=0.05$. Moreover, Table 3 also presents that the result of F-statistic in this study is 4.837 with the significant value of 0.000 which is lower than 0.05 . It means that the model on this study is fit. 
Meanwhile, the Adjusted R Square of this study is 0.402. It means that the independent variables of this study (i.e., external auditor quality and leverage) are able to explain the dependent variable (i.e., tax aggressiveness) by $40 \%$. In the other word, the rest of $60 \%$ is explained by other variables out of the model in this study.

Therefore, the regression eguation in this study is:

TAXAG $=-5.863-0.113 \mathrm{AQ}-0.276 \mathrm{LEV}+\varepsilon$
From the regression equation at above, it could be explained that when the value of external auditors' quality (AQ) and leverage (LEV) is constant, thus TAXAG is -5.863. Moreover, when the value of AQ increases by 1 , meanwhile, LEV is constant so the TAXAG decreases by 0.113 . Similarly, when the value of LEV increases by 1 and AQ is constant thus TAXAG decreases by 0.276

Table 1. Criteria in Sampling Selection

\begin{tabular}{clc}
\hline No & \multicolumn{1}{c}{ Criteria } & \multicolumn{1}{c}{148} \\
\hline 1 & $\begin{array}{l}\text { Manufacturing companies listed on the Indonesian Stock Exchange for 2012-2016 } \\
\text { periods. }\end{array}$ & \\
& $\begin{array}{l}\text { Manufacturing companies that did not issue complete financial statements during } \\
2\end{array}$ & $(6)$ \\
3 & $\begin{array}{l}\text { Manufacturing companies with incomplete data as required in the study respectively } \\
\text { during the 2012-2016 periods }\end{array}$ & $(66)$ \\
\hline $\begin{array}{l}\text { Number of samples } \\
\text { Number of observations for 2012-2016 periods }\end{array}$ & 380 \\
\hline
\end{tabular}

Table 2. Descriptive Statistic

\begin{tabular}{lrrrrr} 
& N & \multicolumn{1}{c}{ Min } & \multicolumn{1}{c}{ Max } & Mean & Std. Dev \\
\hline AQ & 380 & .0 & 1.0 & .786 & .5321 \\
LEV & 380 & .390 & .780 & .536 & .6492 \\
TAXAG & 380 & .120 & .350 & .210 & .5070 \\
\hline
\end{tabular}

Table 3. One-Sample Kolmogorov-Smirnov Test

\begin{tabular}{llr}
\hline & & Unstandardized Residual \\
\hline $\mathrm{N}$ & & 380 \\
Normal & Mean & 2.6388989 \\
Parameters & a,b & Std. Deviation \\
& & .6564621 \\
Most & Absolute & .228 \\
Extreme & Positive & .096 \\
Differences & Negative & -.228 \\
Kolmogorov-Smirnov Z & 1.381 \\
Asymp. Sig. (2-tailed) & .129 \\
\hline
\end{tabular}
a. Test distribution is Normal.
b. Calculated from data. 
Table 4. Heteroscedasticity Test by Using Park Gleyser.

\begin{tabular}{|c|c|c|c|c|c|}
\hline \multicolumn{6}{|c|}{ Coefficients $^{\mathrm{a}}$} \\
\hline \multirow[b]{2}{*}{ Model } & \multicolumn{2}{|c|}{$\begin{array}{c}\text { Unstandardized } \\
\text { Coefficients }\end{array}$} & \multirow{2}{*}{$\begin{array}{c}\text { Standardized } \\
\text { Coefficients } \\
\text { Beta } \\
\end{array}$} & \multirow[b]{2}{*}{$\mathrm{t}$} & \multirow[b]{2}{*}{ Sig. } \\
\hline & B & $\begin{array}{l}\text { Std. } \\
\text { Error }\end{array}$ & & & \\
\hline 1 (Constant) & .832 & .658 & & 1.236 & .154 \\
\hline $\mathrm{AQ}$ & -.475 & .376 & -.091 & -.796 & .237 \\
\hline LEV & -.165 & .117 & -.095 & -1.326 & .097 \\
\hline
\end{tabular}

a. Dependent Variable: ABRESID

Table 5. The Output of Durbin Watson test

\begin{tabular}{|c|c|c|c|c|c|c|}
\hline \multicolumn{7}{|c|}{ Model Summary $^{\text {b }}$} \\
\hline Model R & & R Square & $\begin{array}{l}\text { Adjusted R } \\
\text { Square }\end{array}$ & $\begin{array}{l}\text { Std. Error of } \\
\text { the Estimate }\end{array}$ & $\begin{array}{l}\text { Durbin- } \\
\text { Watson }\end{array}$ & \\
\hline 1 & $.580^{\mathrm{a}}$ & .421 & .402 & .500492 & & 1.886 \\
\hline
\end{tabular}

Table 6. The Output of Multicollinearity Test

\begin{tabular}{lcc}
\hline Variabel & Tolerance & VIF \\
\hline AQ & 0.782 & 1.011 \\
LEV & 0.548 & 2,182 \\
\hline
\end{tabular}

Table 7. The Results of Regression Analysis

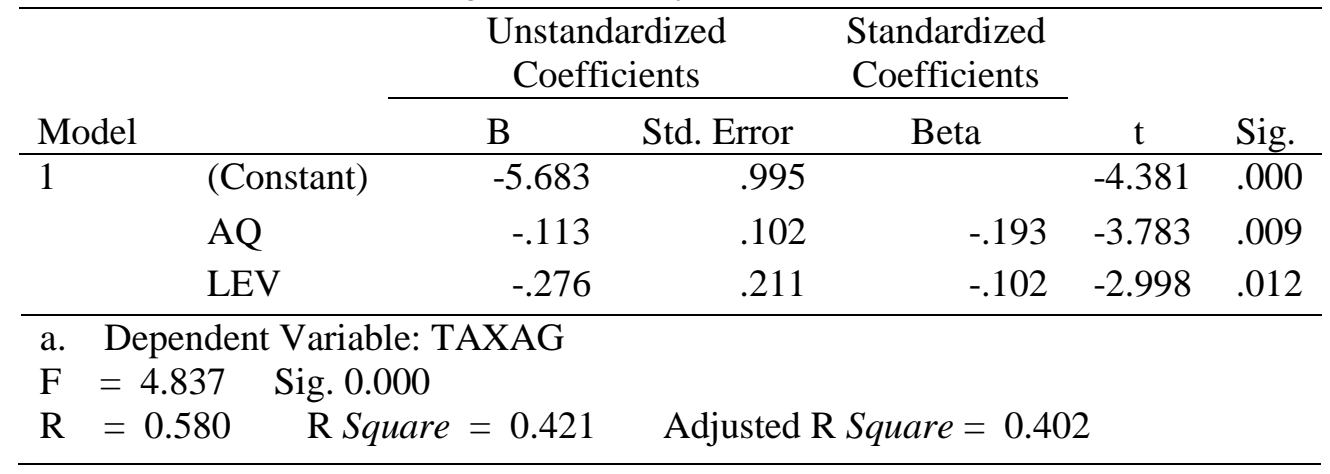




\section{Discussion}

The first hypothesis in this study states that the auditor quality affects negatively on tax aggressiveness. The result of regression analysis in this study shows that there is a significant negative relationship between the two variables, so the first hypothesis is supported. It means that when firms are audited by qualified auditors from the Big 4 public accounting firms will be better able to minimize the behavior of managers in tax aggressiveness than those firms which are audited by auditors from non-Big 4 public accounting firms. The findings of this study support Barrett (2004) argument stating that the auditor is responsible for examining the company's significant accounts including a large amount of tax expense which is generally significant. So when a company is audited by a higher-quality of public accounting firms, the auditor will run a closer inspection of the income tax account than what the non-Big 4 public accounting firms do. This conditions will have implications that a firm audited by Big 4 public accounting firms will lessen its tax aggressive behavior than firms audited by a non-Big 4 public accounting firms.

Furthermore, the findings in this study are also in line with Dhaliwal et al. (2004), Frank et al. (2009), Hanlon et al. (2012), and Gupta et al. (2016) stating that the more qualified an auditor (i.e., Big 4 public accounting firms) will increasingly be able to control the aggressive tax behavior of clients because such behavior increases the material misstatement in the financial statement and also implies the greater the legal problems for auditor later in the day when the government finds the tax violations committed by the client. In this case, the government will accuse the auditor of not working in accordance with a code of professional ethics so that the profession can not suppress the client not to behave aggressively in fulfilling its tax obligations to the state (Heninger, 2001; Palmrose \& Scholz, 2004). In general, the findings in this study are also in line with some previous studies which suggest that the larger the size of public accounting firms will be more reputable so that Big 4 public accounting firms are better able to prevent clients from behaving aggressively in their tax obligations than those non-Big 4 public accounting firms (Choi et al., 2008; Francis \& Wang, 2008; Kanagaretnam et al., 2010). It is also in line with several studies documenting that aggressive tax planning is more prevalent in firms audited by non-Big 4 public accounting firms than those firms audited by Big 4 public accounting firms (Frank et al., 2009; Donohoe \& Knechel, 2014; Klassen et al ., 2016).

The second hypothesis in this study states that leverage has a negative effect on tax aggressiveness. The result of regression analysis in this study found that leverage has a negative effect on tax aggressiveness, so the second hypothesis is supported. It means that the findings in this study support the argument that the high rate of the company's debt will cause the company to pay a high-interest expense that will eventually reduce the tax liability in the current year. Thus, when the company's earnings decrease due to the high-interest expense to be paid then the opportunity of companies make efforts to avoid taxes will also decline.

The findings in this study are in line with Ozkan (2001) who provided evidence that firms with high tax liabilities will choose to make new loans in order to reduce taxes. When a company makes loans intentionally to reduce the tax expense, it can be mentioned that the company is aggressive against taxes. To avoid the use of $100 \%$ of debt in business financing then should be considered as well the cost of debt or financial distress, also called cost of bankruptcy which causes the company cannot achieve optimal profit from $100 \%$ debt financing. Cost of bankruptcy includes direct costs in the form of legal costs and administration of corporate liquidation including reorganization costs as well as indirect 
costs. The company also tends to use internal financing sources first, then debt and equity respectively. Furthermore, the results of this study support Richardson and Lanis (2007) which states that leverage negatively affects the avoidance of taxes. The higher the leverage ratio, the higher the amount of funding from third-party debt used by the company and the higher the interest expense arising from the debt. Higher interest rates will reduce the company's tax expense. Therefore, the tax aggressive behavior will decline when the amount of tax is already law. In the other word, the company will deem not in urgent need to do tax avoidance or evasion when the company tax is low due to the high debt ratio in the company capital structure.

\section{CONCLUSION}

This study intends to examine the influence of auditor quality and leverage on tax aggressiveness in manufacturing companies listed on the Indonesian Stock Exchange. By using purposive sampling approach, this study got 76 manufacturing companies as a sample during 2012-2016 periods, so totally there are 380 observations. The result of the analysis in this study concludes that both auditor quality and leverage have a negative effect on tax aggressiveness at manufacturing companies listed on the Indonesia Stock Exchange.

The theoretical implication that can be obtained from this study is that the results of this research can add insight and knowledge for the development of science in the field of financial accounting and taxation especially related to aggressive tax behavior by corporations as taxpayers. While practically, this research is beneficial to the Indonesian Government both the Directorate General of Tax and Financial Services Authority regarding the importance of the company to be audited by a qualified auditor because it will be able to reduce aggressive tax behavior from the corporations as taxpayers. For further researchers who are interested in researching the same topic, can further develop this research model with different settings, population, and independent variables.

\section{REFERENCES}

Annisa, N.A., \& Kurniasih, L. (2012). The Effect of Corporate Governance on Tax Avoidance (translation from the Indonesian Language). Jurnal Akuntansi dan Auditing, 8(2), 95189.

Armstrong, C., Blouin, J., Jagolinzer, A., \& Larcker, D.F. (2015). Corporate Governance, Incentives, and Tax Avoidance. Journal of Accounting and Economics.60(1), 1-17.

Astuti, T.P., \& Aryani, Y.A. (2016). The Trend of Tax Avoidance from Manufacturing Companies Listed on the Indonesian Stock Exchange for 2011-2014 Periods (translation from the Indonesian Language). Jurnal Akuntansi, 20(3), 375-388.

Barrett, M. J. (2004). Tax Services as A Trojan Horse in The Auditor Independence Provisions of Sarbanes-Oxley. Michigan State Law Review, 463-504.

Choi, J.H., Kim, J.B., Liu, X., \& Simunic, D. (2008). Audit Pricing, Legal Liability Regimes, and Big 4 Premiums: Theory and CrossCountry Evidence. Contemporary Accounting Research, 25, 55-99.

Desai, M., \& Dharmapala, D. (2006). Corporate Tax Avoidance and HighPowered Incentives. Journal of Financial Economics, 79(1), 145179.

Dhaliwal, D., Gleason, C., \& Mills, L. (2004). Last-Chance Earnings Management: Using The Tax Expense to Meet Analysts' Forecasts. 
Contemporary Accounting Research, 21(2), 431-459.

Donohoe, M.P., \& Knechel, W.R. (2014). Does Corporate Tax Aggressiveness Influence Audit Pricing?. Contemporary Accounting Research, 31(1), 284-308.

Dyreng, S.D., Hanlon, M., \& Maydew, E.L. (2008). Long-Run Corporate Tax Avoidance. The Accounting Review, 83(1), 61-82.

Eschborn, (2010). Addressing Tax Evasion and Tax Avoidance in Developing Countries. Deutsche Gesellschaft fur, Internationale Zusammenarbeit (GIZ) $\mathrm{GmbH}$, Germany.

Farooque, O.A., Suyono, E., \& Rosita, U. 2014. Link Between Market Return, Good Governance, and Earnings Management: Emerging Market Perspective. Corporate Ownership and Control, 11(2), 192-211.

Francis, J., Philbrick, D., \& Schipper, K. (1994). Shareholder Litigation and Corporate Disclosures. Journal of Accounting Research, 32, 137-164.

Francis, J., \& Wang, D. (2008). The Joint Effect of Investor Protection and Big 4 Audits on Earnings Quality around The World. Contemporary Accounting Research, 25, 1-39.

Frank, M., Lynch, L., \& Rego, S. (2009). Tax Reporting Aggressiveness and Its Relation to Aggressive Financial Reporting. The Accounting Review, 84, 467-496.
Gallemore, J., Maydew, E., \& Thornock, J. (2014). The Reputational Costs of Tax Avoidance. Contemporary Accounting Research, 31(4), 11031133.

Gupta, S., Laux, R., \& Lynch, D. (2016). Do Firms Use Tax Reserves to Meet Analysts' Forecasts? Evidence from The Pre- and Post-FIN 48 Periods. Contemporary Accounting Research, 33(3), 1044-1074.

Gupta, S., \& Newberry, K. (1997). Determinants of The Variability in Corporate Effective Tax Rates: Evidence from Longitudinal Study. Journal of Accounting and Public Policy, 16, 1-34.

Hanlon, M., \& Heitzman, S. (2010). A Review of Tax Research. Journal of Accounting and Economics, 50, 127178.

Hanlon, M., Krishnan, G.V., \& Mills, L.F. (2012). Audit Fees and Book-Tax Differences. Journal of the American Taxation Association, 34, 55-86

Hanlon, M., \& Slemrod, J., 2009. What Does Tax Aggressiveness Signal? Evidence from Stock Price Reactions to News about Tax Shelter Involvement. Journal of Public Economics, 93, 126-141.

Heninger, W. (2001). The Association Between Auditor Litigation and Abnormal Accruals. The Accounting Review, 76(1), 111-126.

Hennes, K.M., Leone, A.J., \& Miller, B.P. (2014). Determinants and Market Consequences of Auditor Dismissals after Accounting Restatements. The Accounting Review, 89(3), 10511082. 
Hertog, J.D. (1999). General Theories of Regulation. Working Paper, Economic Institute/ CLAV, Utrecht University.

Hertog, J.D. (2010). Review of Economic Theories of Regulation. Working Paper, Utrecht School of Economics, Utrecht University.

Indonesian Law No. 36 of 2008 Concerning Income Tax.

Kanagaretnam, K., Lim, C.Y., \& Lobo, G.J. (2010). Auditor Reputation and Earnings Management: International Evidence from The Banking Industry. Journal of Banking and Finance, 34, 2318-2327.

Kanagaretnam, K., Lee, J., Lim, C.Y., \& Lobo, G.J. (2016). Does Auditor Quality Constrain Corporate Tax Avoidance? Some International Evidence. Auditing A Journal of Practice \& Theory, 35(4), 105-135.

Kim, J.B., Li, Y., \& Zhang, L. (2011). Corporate Tax Avoidance and Stock Price Crash Risk: Firm-Level Analysis. Journal of Financial Economics, 100, 639-662.

Klassen, K., Lisowsky, P., \& Mescall, D. (2016). The Role of Auditors, NonAuditors, and Internal Tax Departments in Corporate Tax Aggressiveness. The Accounting Review, 91(1), 179-205.

Kurniasih, T., \& Sari, M.R. (2013). The Effect of Return on Assets, Leverage, Corporate Governance, Company Size, and Fiscal Loss Compensation on Tax Avoidance (translation from the Indonesian Language). Buletin Studi Ekonomi, 18(1),58-65.
Langli, J.C., \& Willekens, M. (2017). Tax Avoidance, Horizontal Agency Conflicts and High-Quality Auditing in Private Firms. Proceeding of the 2017 Scandinavian Accounting Research Conference, Norway.

Lennox, C., Lisowsky, P., \& Pittman, J. (2013). Tax Aggressiveness and Accounting Fraud. Journal of Accounting Research, 51(4),739-778.

Lisowsky, P. (2010). Seek Shelter: Empirically Modeling Tax Shelters Using Financial Statement Information. The Accounting Review, 85(5), 1693-1720.

Mansi, S.A., Maxwell, W.F., \& Miller, S.P. (2004). Does Auditor Quality and Tenure Matter To Investors? Evidence from the Bond Market. Journal of Accounting Research, 42, 755-793.

Mansor, M., \& Gurama, Z. (2016). Factors Influencing Tax Evasion in Gombe State Nigeria. Proceeding of International Soft Science Conference 2016, Langkawi, Malaysia.

McGuire, S.T., Omer, T.C., \& Wang, D. (2012). Tax Avoidance: Do Industry Experts Make A Difference?. The Accounting Review, 87(3), 975-1003.

Ozkan, A. (2001). Determinants of Capital Structure and Adjustment to Long Run Target: Evidence from UK Company Panel Data. Journal of Bussiness Finance and Accounting, 28 (1) \& (2).175-198.

Palmrose, Z., \& Scholz, S. (2004). The Circumstances and Legal Consequences of Non-GAAP Reporting: Evidence from Restatements. Contemporary Accounting Research, 21, 139-180. 
Richardson, G., \& Lanis, R. (2007). Determinants of Variability in Corporate Effective Tax Rates and Tax Reform: Evidence From Australia. Journal of Accounting and Public Policy, 26, 689-704.

Sartori, N. (2008). Effect of Strategic Tax Behaviors on Corporate Governance. Available on: www.ssrn.com.

Siegfried, J.J. (1972). The Relationship Between Economic Structure and The Effect of Political Influence: Empirical Evidence from the Federal Corporation Income Tax Program. Ph.D. Dissertation, University of Wisconsin, Madison.

Simser, J. (2008). Tax Evasion and Avoidance Typologies. Journal of Money Laundering Control, 11(2), $123-134$.

Stickney, C.P., \& McGee, V.E. (1982). Effective Corporate Tax Rates: The Effect of Size, Capital Intensity, Leverage, and Other Factors. Journal of Accounting and Public Policy, 1, 125-152.

Swingly, C., \& Sukartha, I.M. (2015). The Effect of Executive Character, Audit Committee, Company Size, Leverage, and Sales Growth on Tax Avoidance (translation from the Indonesian Language). E-Jurnal Akuntansi Universitas Udayana, 10(1), 47-62.
Watts, R., \& Zimmerman, J. (1986). Positive Accounting Theory. Englewood Cliffs, New Jersey: Prentice-Hall.

Zimmerman, J.L. (1983). Taxes and Firm Size. Journal of Accounting and Economics, 5, 119-149. 